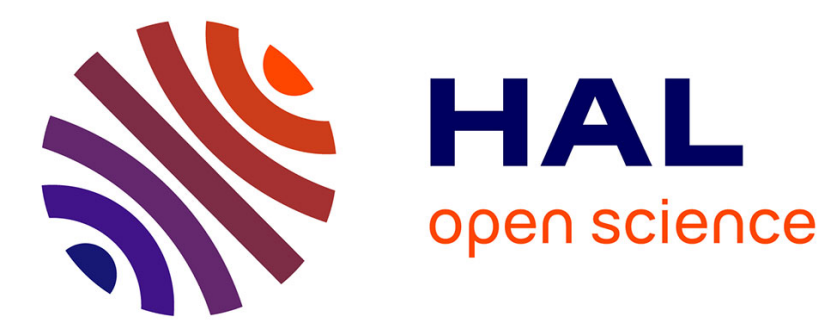

\title{
Heritability of the character "secondary blooming" on pear (Pyrus communis)
}

Bernard Thibault, C. Welcker, Yves Lespinasse

\section{To cite this version:}

Bernard Thibault, C. Welcker, Yves Lespinasse. Heritability of the character "secondary blooming" on pear (Pyrus communis). Acta Horticulturae, 1983, 139, pp.181-193. hal-01601676

\section{HAL Id: hal-01601676 \\ https://hal.science/hal-01601676}

Submitted on 1 Jun 2020

HAL is a multi-disciplinary open access archive for the deposit and dissemination of scientific research documents, whether they are published or not. The documents may come from teaching and research institutions in France or abroad, or from public or private research centers.
L'archive ouverte pluridisciplinaire HAL, est destinée au dépôt et à la diffusion de documents scientifiques de niveau recherche, publiés ou non, émanant des établissements d'enseignement et de recherche français ou étrangers, des laboratoires publics ou privés.

\section{다(1) (2)}

Distributed under a Creative Commons Attribution - ShareAlikel 4.0 International 
HERITABILITY OF THE CHARACTER "SECONDARY BLOOMING" ON PEAR (Pyrus communis).

B.THIBAULT, C. WELCKER, Y. LESPINASSE

Station d'Arboriculture Fruitière

I.N.R.A. - Bois l'Abbé,

BEAUCOUZE - 49000 ANGERS (France)

\section{Abstract}

The progenies of 12 parents were registred in june, july and august for the character "secondary blooming", responsable of the great susceptibility of the cultivar PASSE CRASSANE to fire blight in the south west of France.

The mean values of these progenies allowed to build up four groups. PRESIDENT DROUARD, DUCHESSE DE MOUCHY and DOYENNE DU COMICE belong to the first group where the progenies show few secondary blossoms whereas the progenies of PASSE CRASSANE and BEURRE D'AVRIL have many seedlings with this characteristic. For some parents the observed values are extremely variable according to the combinations.

Analysis with the Griffing method of a partial diallel with 7 parents and 21 progenies allowed to estimate the general and specific combining abilities for this character.

\section{Introduction}

Secondary blossoms are the main entry of the bacteria responsible of Fire blight on the pear variety PASSE CRASSANE in the South West of France.

In 1979 and 1980 we observed the importance of that phenomenon in some pear progenies. These progenies belonged to a half diallel (excluding the reciprocals and the parental lines) bred at Angers since 1962. In 1980 some progenies were already discarded either completely either partially. Thus the effectives by progeny were irregular.

Two models of analysis were choosen :

1 - analysis of the value of parents for transmitting this character. This analysis concerns 12 parents used in the initial diallel.

2 - analysis by the GRIFFING's model concerning a sub-set of the initial diallel. This new half diallel was made up rom 7 parents and included 21 progenies of 38 hybrids planted with no replications. This analysis allowed us to estimate the General Combining Ability (G.C.A.) and the Specific Combining Ability (S.C.A.) for this character.

First analysis

We had at our disposal a partial incomplete diallel between 12 parents: PASSE-CRASSANE, PRESIDENT DROUARD, DUCHESSE DE MOUCHY, CONFERENCE, DOYENNE DU COMICE, DOYENNE D'HIVER, NOTAIRE LEPIN, REMY CHATENAY, DOYENNE PERRAULT, BEURRE D'AVRIL, MADAME BALLET, JEANNE D'ARC. 
Theoretically we should obtain 66 progenies but we could observe only 58. The effectives varied from 27 to 207 hybrids by progeny and a total of 5136 trees were observed (Table 1).

Three observations were recorded : 10th June - 3d July - 23d August Each tree is noted from $\mathrm{O}$ to 6 according to the following code :

Note

Number of second. flow./tree
O 1

O

$1-5$
2

$6-10$
3

$11-15 \quad 16-20$
5

$21-25$
6

25

\section{A) Observation of the families}

The progeny of each parent make a family of half sibs. The effectives of these families varied from 587 to 1119. Table 2 shows the adjusted means for the twelve families and their variance for the three observations. The analysis of variance indicates highly significant differences between the values for the three dates.

We observed that :

- DUCHESSE DE MOUCHY and PRESIDENT DROUARD transmit to their seedlings a low intensity of secondary blossoms.

- Whatever the parents this intensity decrease in July and August.

- Progenies of PASSE CRASSANE and particularly of BEURRE D'AVRIL show, even in August a rather high intensity of secondary blossoms.

- Progenies of some parents (as PASSE CRASSANE and BEURRE d'AVRIL) have not an homogeneous behaviour (high variance).

The figure 1 illustrates this behaviour.

Using DUNCAN'S multiple range test at the $5 \%$ level a classification was established for these twelve families. Table 3 shows, only for June, this classification and the phenotypic tendency of the parents. Figure 2 summarizes these values for the three dates and allows us to establish four groups of parents :

- DUCHESSE DE MOUCHY, PRESIDENT DROUARD, DOYENNE DU COMICE.

- DOYENNE DU COMICE, REMY CHATENAY, NOTAIRE LEPIN, CONFERENCE, DOYENNE D'HIVER, MADAME BALLET.

- DOYENNE D'HIVER, MADAME BALLET, JEANNE D'ARC, DOYENNE PERRAULT.

- BEURRE D'AVRIL, PASSE CRASSANE.

B) Observation of the progenies

It is interesting to note that some progenies showed no secondary blossoms neither in June nor in July or August :

- DUCHESSE DE MOUCHY x PRESIDENT DROUARD

57 trees

- DUCHESSE DE MOUCHY x CONFERENCE 22

- DUCHESSE DE MOUCHY X DOYENNE DU COMICE

51

- DUCHESSE DE MOUCHY X REMY CHATENAY

64

- DOYENNE DU COMICE X MADAME BALLET

- PRESIDENT DROUARD X MADAME BALLET 91 70 ,

Some other progenies have high means specially with PASSE CRASSANE and BEURRE D'AVRIL. 
These results are in agreement with those obtained the previous year (THIBAULT, 1979).

Second analysis

The progenies still alive in the field in 1980 allow us to establish a half diallel including 7 parents : PASSE CRASSANE, DUCHESSE DE MOUCHY, CONFERENCE, DOYENNE PERRAULT, BEURRE D'AVRIL, MADAME BALLET, JEANNE D'ARC.

Absence of reciprocals and self fertilization led us to follow the GRIFFING'S analysis, Method 4. As the parents are assumed to be a choosen set we use the Model I (GRIFFING, 1956)*.

We will limit this note to the results of the observations made in June:

- The differences between the 21 progenies are high significant.

- A DUNCAN'S multiple range test at the $5 \%$ level allowed us to make a classification (Table 4).

- Table 5 shows the means for each parental family.

- We have a highly significant effect for General Combining Ability (G.C.A.) and a significant effect for Specific Combining Ability (S.C.A.).

- The ratio between the mean squares of G.C.A. and S.C.A. $(=6,50)$ indicates that additivity is more concerned than the other genetic effects.

- As the effects due to the G.C.A. were all significant, their classification was made (Table 6) : DUCHESSE DE MOUCHY and CONFERENCE are different from all the others and have a high G.C.A. (negative). On the other hand BEURRE D'AVRIL shows the highest positive value.

- The variances of G.C.A. associated with each parent are low for JEANNE D'ARC, DOYENNE PERRAULT and MADAME BALLET and high for DUCHESSE DE MOUCHY.

- Estimates of S.C.A. constants are showed in the table 7 and in the figure 3 .

- JEANNE D'ARC, PASSE CRASSANE and DOYENNE PERRAULT show the greatest variation depending to the other parent. The extreme values were obtained by DOYENNE PERRAULT $X$ JEANNE D'ARC and PASSE CRASSANE X DUCHESSE DE MOUCHY on the one hand (negative values) and by PASSE CRASSANE $X$ JEANNE D'ARC and DOYENNE PERRAULT $X$ BEURRE D'AVRIL on the other hand (positive values). The values for MADAME BALLET are the most concentrated.

- Table 7 shows also the variances of S.C.A. associated with each parent: DUCHESSE DE MOUCHY, CONFERENCE and MADAME BALLET have the lowest estimates and JEANNE D'ARC and PASSE CRASSANE the highest.

A brief summary of results indicates that :

- DUCHESSE DE MOUCHY and CONFERENCE have the best G.C.A. and a low variation of their S.C.A. they will have progenies with few secondary blossoms whatever the second parent.

* The authors gratefully acknowledge the contribution of J.D. FLICK for preparing the computer program. 
- JEANNE D'ARC shows a G.C.A. negative but close to zero. However this parent shows a high variation for the S.C.A. : some combinations with JEANNE D'ARC will have a high level of secondary blossoms. Others will have a low one.

- This variability of S.C.A. is high too for PASSE CRASSANE and moreover the G.C.A. is positive. Some but few combinations with this parent may be interesting.

\section{Conclusion}

These two types of analysis are in concordance. Analysis by the GRIFFING'S method brings fuller information appreciable for building an accurate breeding program. The fixed model limits the use of these results only to parents involved in this analysis. All other combination shoud be entered in a new experimentation and a new analysis.

\section{References}

Thibault, B., 1979. Etude de la transmission de quelques caractères dans des descendances de Poirier : II. Production de secondes floraisons. EUCARPIA - Section Fruits - Symposium Angers.

Griffing, B., 1956. Concept of General and Specific Combining Ability in relation to diallel crossing systems. Aust. J. Biol. Sci. 9 : 463-493. 
Table 1 - Incomplete half diallel.

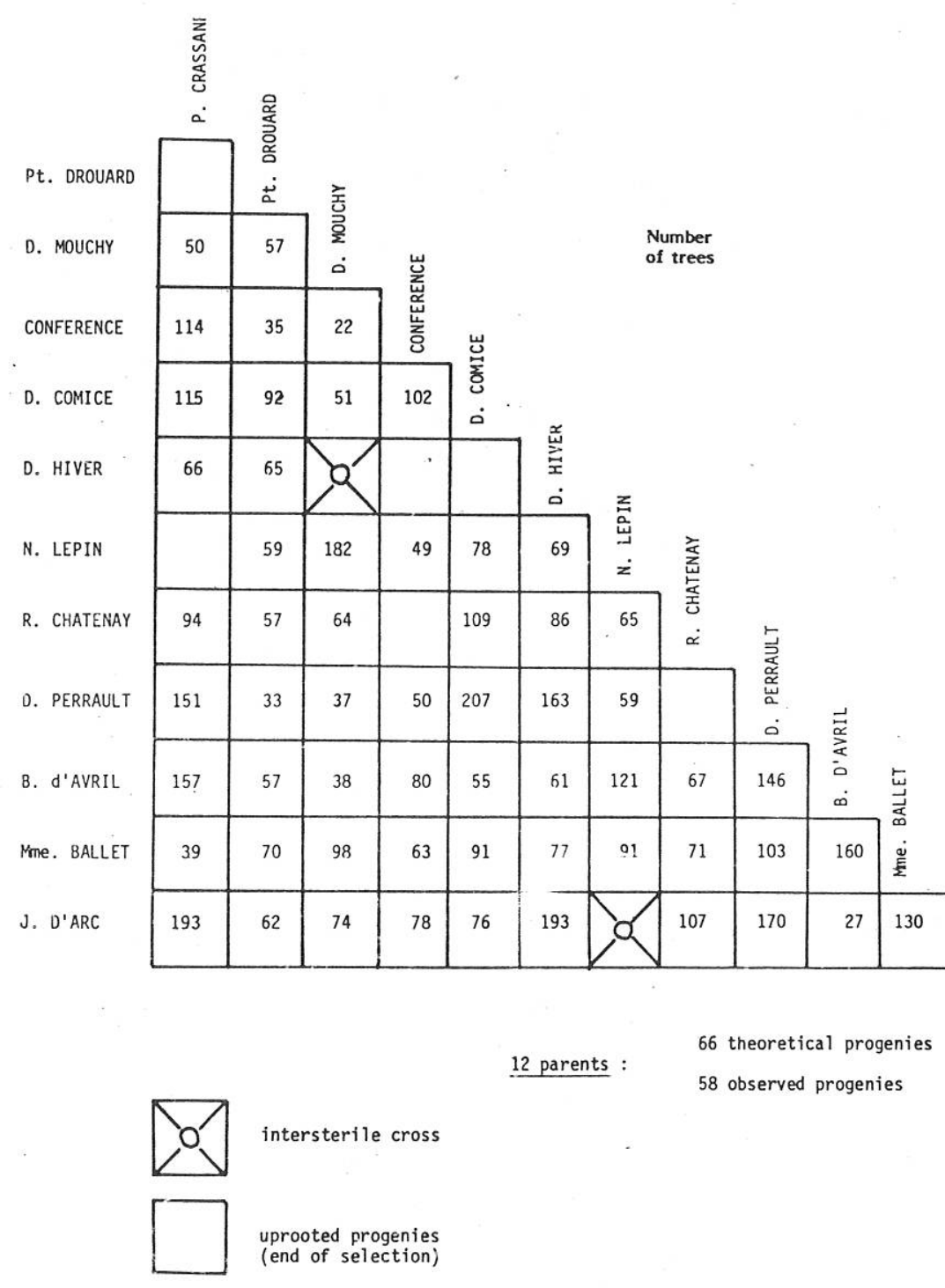




\begin{tabular}{|c|c|c|c|c|c|}
\hline$\dot{8}$ & $\stackrel{O}{\rightrightarrows}$ & 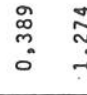 & \begin{tabular}{c}
$\circ$ \\
$\stackrel{\circ}{\circ}$ \\
\hdashline \\
0
\end{tabular} & $\begin{array}{l}\tilde{N} \\
0 \\
0\end{array}$ & $\begin{array}{l}\infty \\
0 \\
0 \\
0\end{array}$ \\
\hline $\begin{array}{l}\dot{m} \\
\dot{\Sigma}\end{array}$ & \%ั & $\begin{array}{ll}0 & 0 \\
\text { d } & 0 \\
0\end{array}$ & $\stackrel{\sim}{\approx}$ & $\begin{array}{l}\vec{a} \\
0\end{array}$ & $\begin{array}{l}\infty \\
0 \\
0 \\
0\end{array}$ \\
\hline$\dot{8}$ & ㅇํㅇ & $\begin{array}{ll}N & 0 \\
0 & 0 \\
0 & 0\end{array}$ & $\stackrel{\sim}{\stackrel{n}{m}}$ & $\begin{array}{l}0 \\
0 \\
0 \\
0\end{array}$ & $\overrightarrow{\tilde{m}}$ \\
\hline $\begin{array}{l}\dot{0} \\
\dot{0}\end{array}$ & $\stackrel{\Xi}{\rightrightarrows}$ & \begin{tabular}{l}
$\stackrel{N}{N}$ \\
\multirow{0}{*}{} \\
0
\end{tabular} & $\begin{array}{l}\vec{m} \\
\stackrel{0}{0}\end{array}$ & $\begin{array}{l}\overrightarrow{0} \\
0 \\
0 \\
0\end{array}$ & 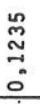 \\
\hline $\begin{array}{l}\dot{\alpha} \\
\dot{\alpha}\end{array}$ & $\stackrel{\sim}{\sim}$ & $\begin{array}{ll}\vec{\sigma} & \stackrel{\infty}{=} \\
\overrightarrow{0} & 0\end{array}$ & $\begin{array}{l}\stackrel{0}{0} \\
\vdots \\
0\end{array}$ & $\begin{array}{l}\overrightarrow{0} \\
0\end{array}$ & $\begin{array}{l}\vec{\circ} \\
0\end{array}$ \\
\hline $\begin{array}{l}\dot{j} \\
\dot{z}\end{array}$ & $\stackrel{m}{\sim}$ & $\begin{array}{ll}\vec{m} & \stackrel{n}{m} \\
0 & 0\end{array}$ & $\begin{array}{l}\infty \\
\infty \\
0 \\
0\end{array}$ & $\begin{array}{l}\overrightarrow{\tilde{O}} \\
0\end{array}$ & $\begin{array}{l}\text { \& } \\
0 \\
0\end{array}$ \\
\hline $\begin{array}{l}\dot{x} \\
\dot{a}\end{array}$ & $\stackrel{\infty}{\infty}$ & $\begin{array}{ll}\stackrel{\infty}{\leftrightarrows} & \infty \\
\stackrel{0}{0} & 0\end{array}$ & $\begin{array}{l}\stackrel{n}{-} \\
\stackrel{-1}{0} \\
0\end{array}$ & $\begin{array}{l}9 \\
0 \\
0 \\
0\end{array}$ & $\begin{array}{l}\text { के } \\
\text { व }\end{array}$ \\
\hline $\begin{array}{l}\dot{0} \\
\dot{0}\end{array}$ & $\stackrel{\circ}{a}$ & 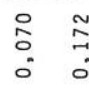 & \begin{tabular}{ll}
$\infty$ & \multirow{2}{n}{} \\
$\tilde{N}$ & 0 \\
0 & 0
\end{tabular} & $\begin{array}{l}0 \\
0 \\
0\end{array}$ & $\begin{array}{l}\stackrel{0}{0} \\
0 \\
0\end{array}$ \\
\hline نं & م్ & 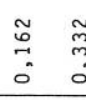 & 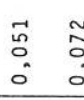 & $\begin{array}{l}\stackrel{0}{*} \\
0 \\
0\end{array}$ & \begin{tabular}{l}
$\stackrel{2}{\cong}$ \\
\hdashline \\
0
\end{tabular} \\
\hline $\begin{array}{l}\Sigma \\
\dot{a}\end{array}$ & $\stackrel{m}{i}$ & 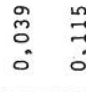 & $\begin{array}{ll}m & m \\
0 & 0 \\
0 & 0\end{array}$ & 0 & 0 \\
\hline $\begin{array}{l}\dot{a} \\
\dot{a}\end{array}$ & in & 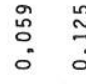 & $\begin{array}{ll}\because & = \\
0 & 0 \\
0 & 0\end{array}$ & 0 & 0 \\
\hline $\begin{array}{l}\dot{0} \\
\dot{a}\end{array}$ & $\stackrel{9}{5}$ & $\begin{array}{ll}\infty & 0 \\
0 & 0 \\
0 & 0 \\
0 & 0\end{array}$ & $\begin{array}{ll}0 & \vec{j} \\
\dot{m} & \infty \\
0 & 0\end{array}$ & $\begin{array}{l}\stackrel{n}{\hat{0}} \\
0 \\
0\end{array}$ & $\stackrel{m}{\sim}$ \\
\hline 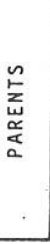 & 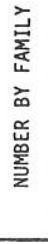 & 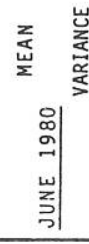 & 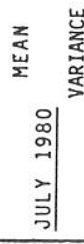 & 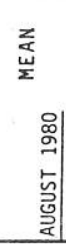 & 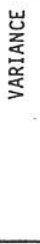 \\
\hline
\end{tabular}




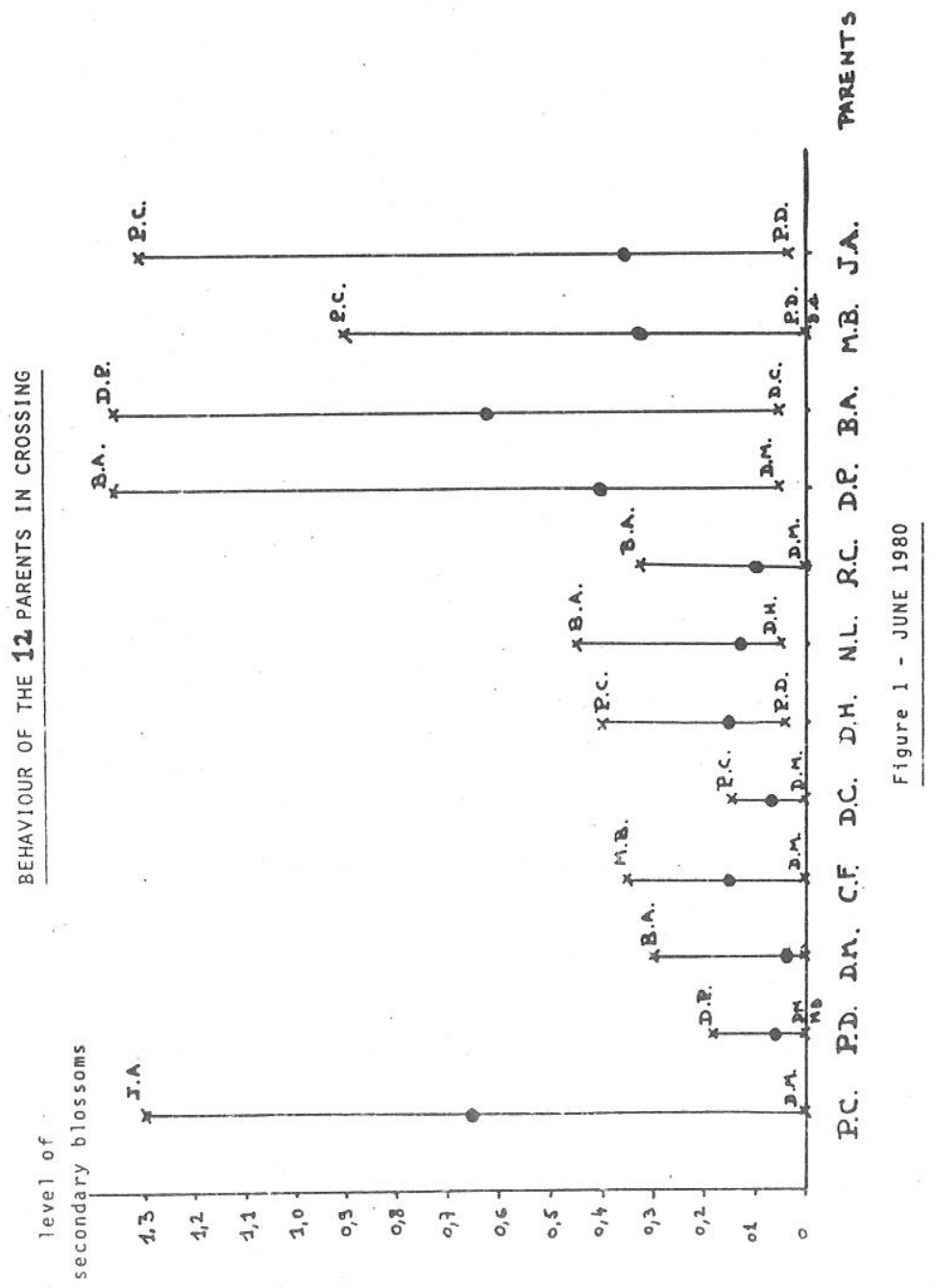


Table 3 - Intensity of secondary blossoms by parental families.

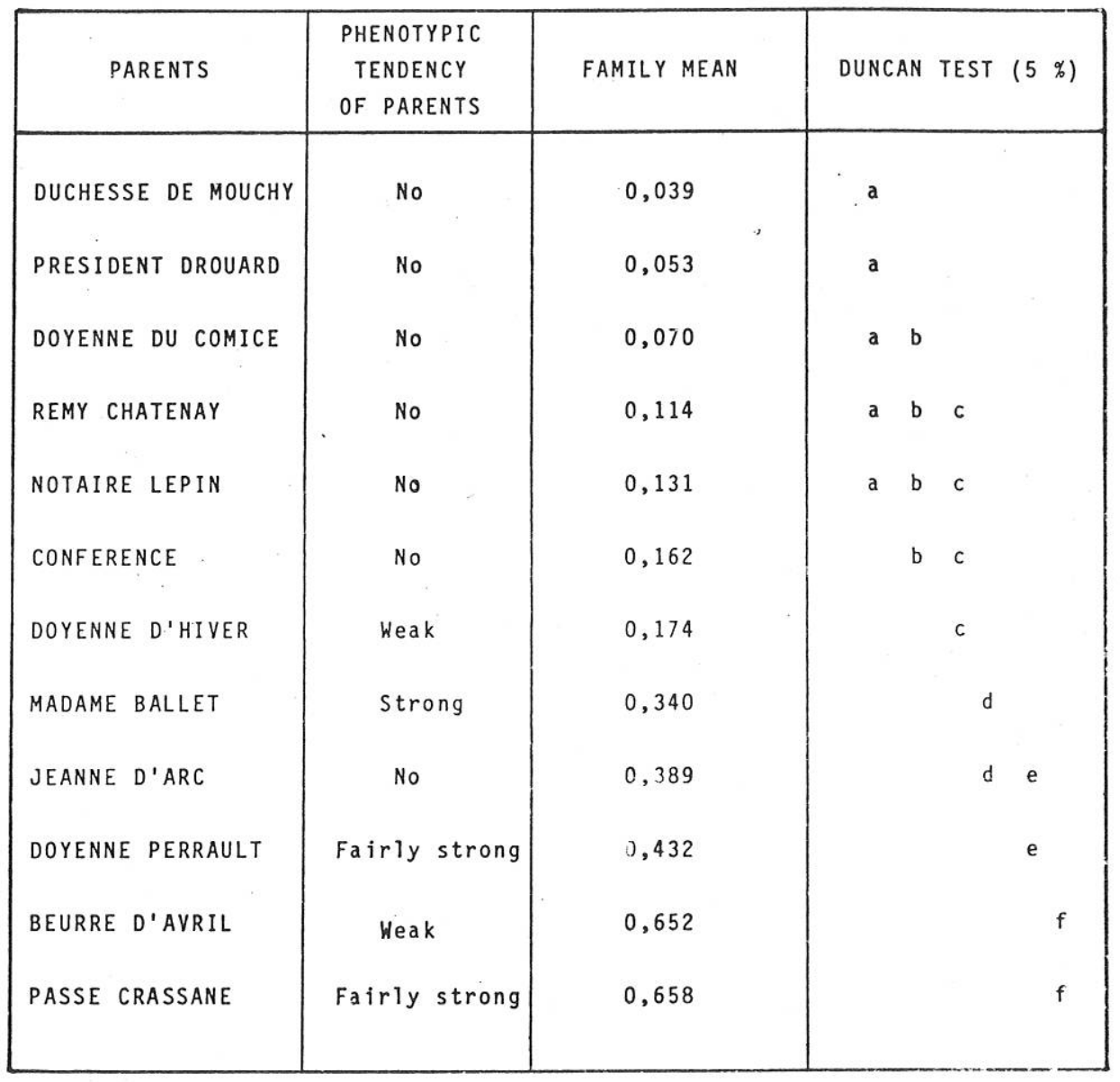




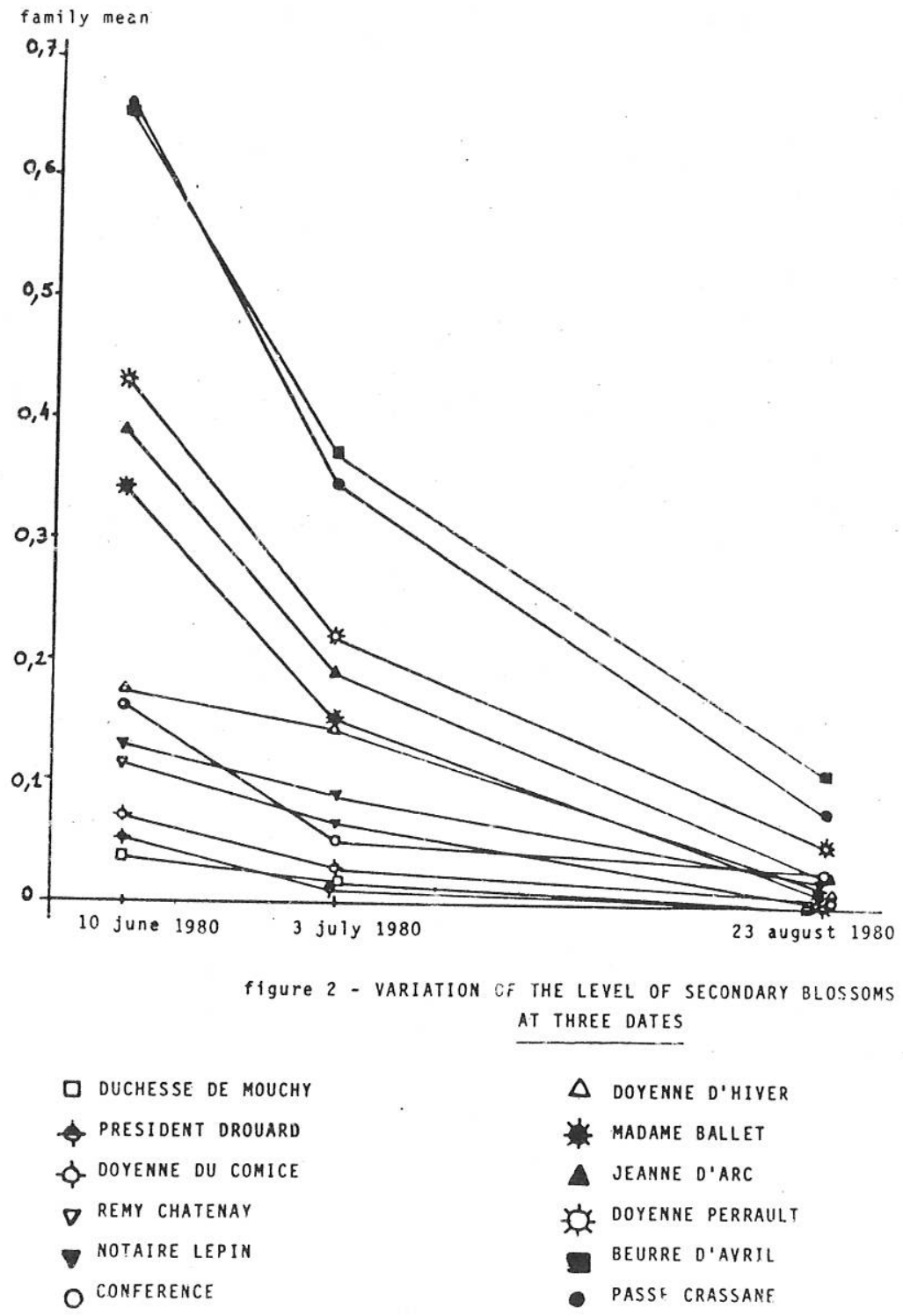


Table 4 - Means, variances and classification of the progenies.

JUNE 1980

\begin{tabular}{|c|c|c|c|c|c|c|c|c|c|c|c|}
\hline \multicolumn{4}{|c|}{ PROGENIES. } & \multirow{2}{*}{$\begin{array}{r}\text { VARI ANCE } \\
0,000\end{array}$} & MEAN & \multicolumn{3}{|c|}{ DUNCAN'S } & \multicolumn{3}{|c|}{ TEST } \\
\hline 7 & D. M. & $x$ & C. F, & & $0,000 *$ & a & & & & & \\
\hline 1 & P. C, & $x$ & D. $M_{1}$ & 0,000 & $0,000 *$ & a & & & & & \\
\hline 8 & D. M. & $x$ & $D_{1} P_{\text {, }}$ & 0,051 & 0,053 & a & & & & & \\
\hline 10 & D. $M_{1}$ & $x$ & $\mathrm{M}_{1} \mathrm{~B}$, & 0,051 & 0,053 & a & & & & & \\
\hline 11 & D. M. & $x$ & $J_{1} A_{1}$ & 0,051 & 0,053 & a & & & & & \\
\hline 15 & C. $F$, & $x$ & J. A. & 0,051 & 0,053 * & $\mathbf{a}$ & & & & & \\
\hline 18 & D. $P_{\text {, }}$ & $x$ & J. A. & 0,074 & $0,079 \approx$ & a & & & & & \\
\hline 12 & C. F, & $x$ & D. $P_{\text {, }}$ & 0,117 & $0,132 *$ & $\mathrm{a}$ & $b$ & c & & & \\
\hline 2 & $P_{1} C_{\text {. }}$ & $x$ & C. $F$, & 0,117 & $0,132 *$ & $\mathrm{a}$ & $\mathrm{b}$ & c & & & \\
\hline 9 & D. M. & $x$ & B. A, & 0,352 & 0,158 & $\mathrm{a}$ & $b$ & c & $d$ & & \\
\hline 13 & C. F, & $x$ & B, A, & 0,185 & 0,237 & $\mathrm{a}$ & $b$ & c & $d$ & e & \\
\hline 21 & M. B, & $x$ & J. A. & 0,293 & $0,237 "$ & $\mathrm{a}$ & $b$ & c & $d$ & e & \\
\hline 14 & $C, F$, & $x$ & M. B. & 0,427 & 0,289 & $\mathrm{a}$ & $b$ & c & $d$ & e & \\
\hline 17 & D. $P$, & $x$ & M. B, & 0,293 & 0,368 & 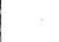 & $b$ & $c$ & $d$ & e & f \\
\hline 4 & $P, C$. & $x$ & $B_{1} A_{1}$ & 0,520 & 0,421 & & & $c$ & $d$ & e & $\mathrm{f}$ \\
\hline 5 & P. C. & $x$ & M. B. & 0,899 & 0,421 & & & c & $d$ & e & f \\
\hline 20 & B. A. & $x$ & J. A. & 0,953 & 0,421 & & & c & $d$ & e & $f$ \\
\hline 3 & P. C. & $x$ & D. $P$, & 0,578 & 0,447 & & & & $d$ & $\epsilon$ & f \\
\hline 19 & B, A, & $x$ & $M, B$, & 0,634 & 0,474 & & & & & e & f \\
\hline 6 & $P, C$. & $x$ & $J_{1} A_{1}$ & 0,785 & 0,605 & & & & & & $f$ \\
\hline 16 & D. $P$, & $x$ & B. A. & 0,779 & 0,632 & & & & & & f \\
\hline
\end{tabular}

* Progeny mean lower than the lower parent. 
Table 5 - Means of the parents.

$\begin{array}{ll}\text { PASSE - CRASSANE } & 0,338 \\ \text { DUCHESSE DE MOUCHY } & 0,053 \\ \text { CONFÉRENCE } & 0,1450 \\ \text { DOYENNE PERRAULT } & 0,285 \\ \text { BEURRE D'AVRIL } & 0,390 \\ \text { MADAME BALLET } & 0,307 \\ \text { JEANNE D'ARC } & 0,241\end{array}$

Table 6 - Classification of the estimates of G.C.A. effects for each parent and estimates of variances associated with each parent.

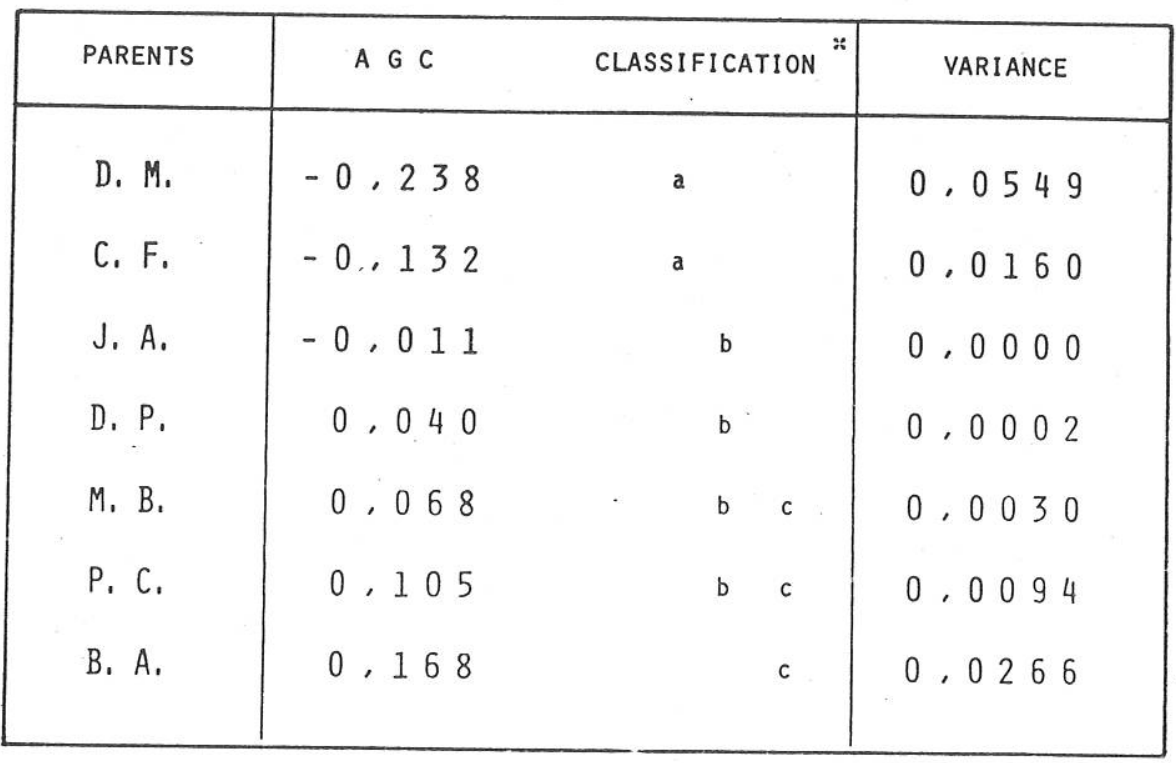

* L S D $5 \%$ 


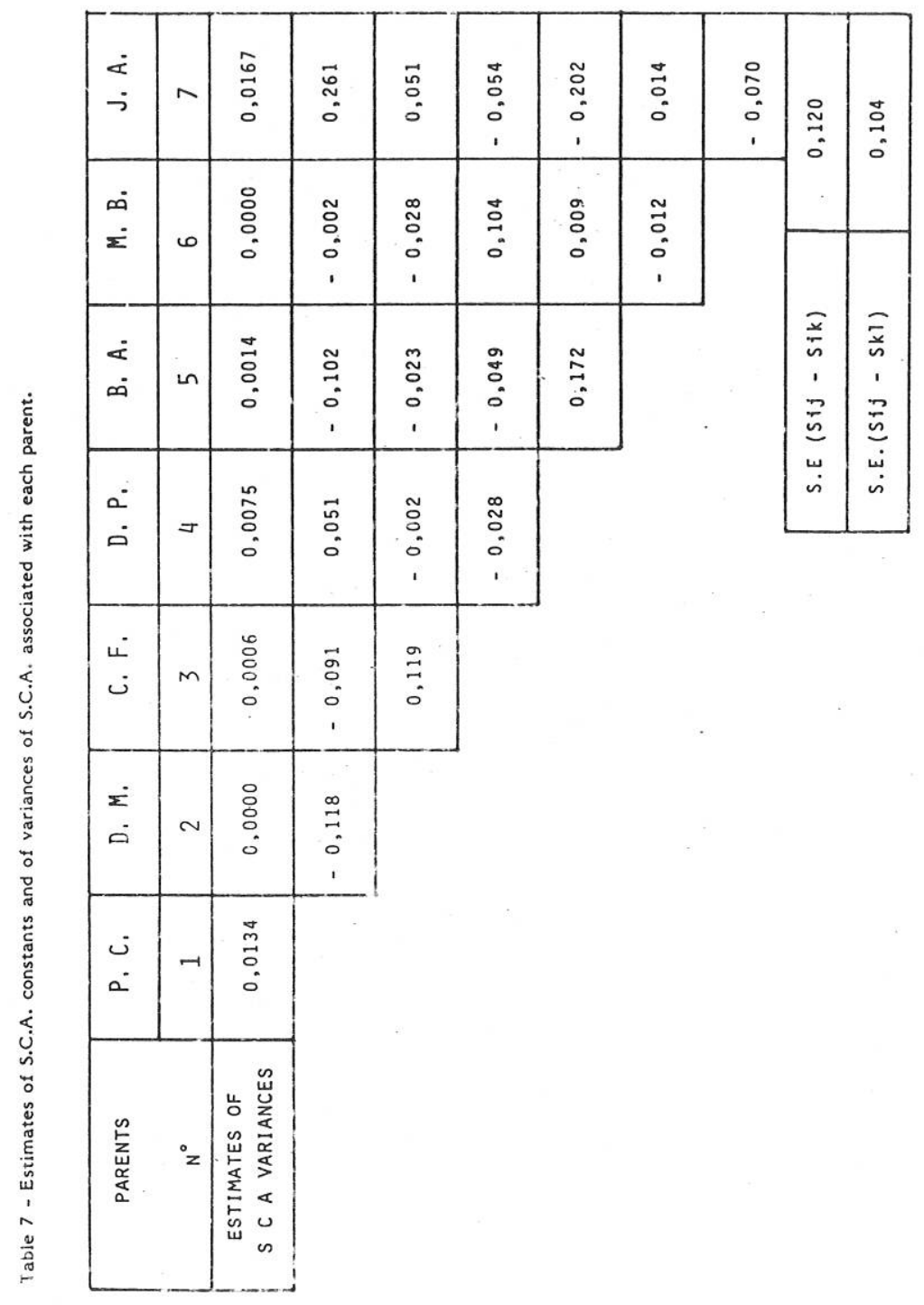




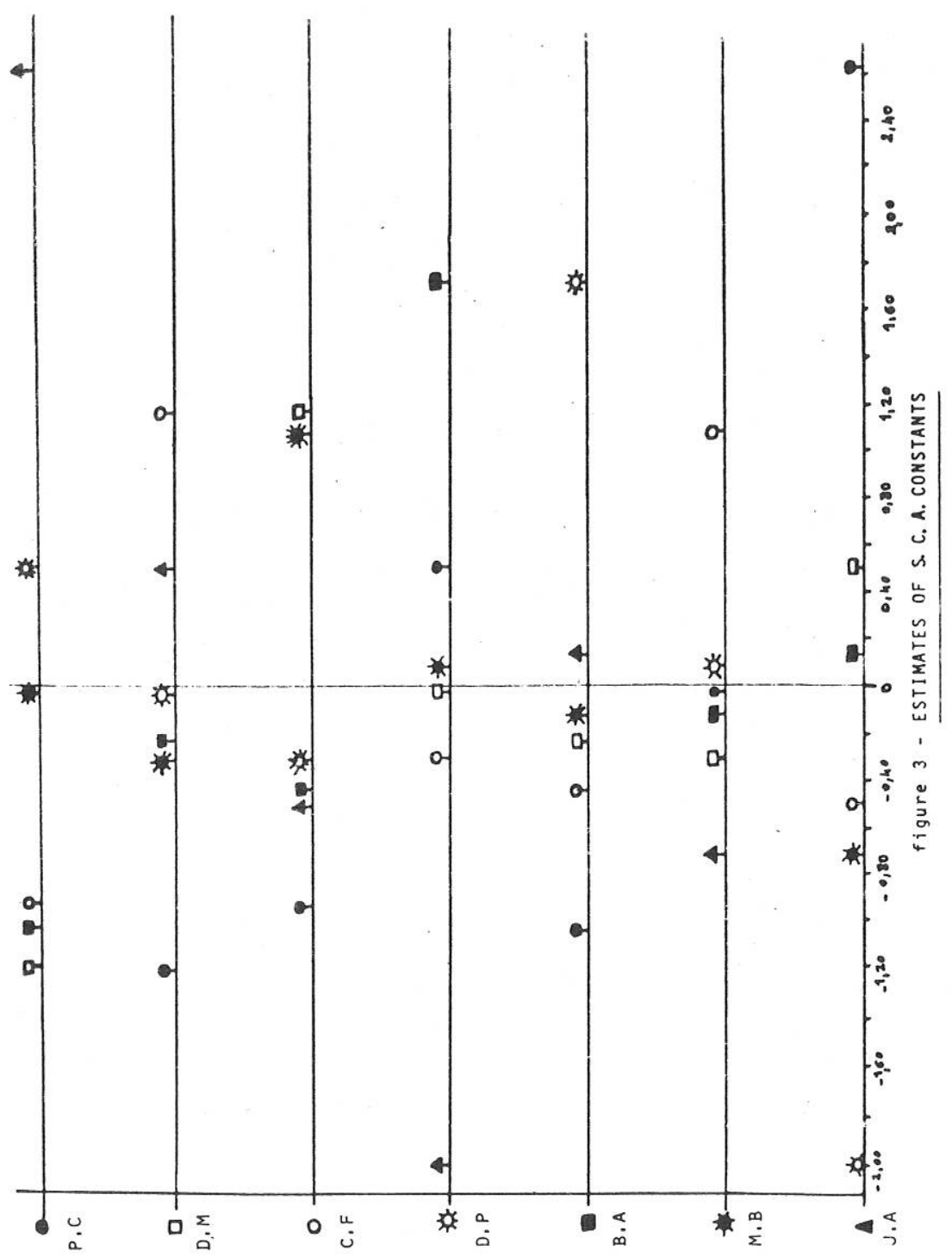

193 
